\title{
The Transition in Solar and Wind Energy Use in Gulf Cooperation Council Countries (GCCC)
}

\author{
Naser Waheeb Alnaser ${ }^{1,{ }^{*}}$, Hanan Mubarak Albuflasa ${ }^{2}$ (D) and Waheeb Essa Alnaser ${ }^{3}$ (D) \\ ${ }^{1}$ College of Engineering, University of Bahrain, PO Box 32038, Kingdom of Bahrain \\ ${ }^{2}$ College of Science, University of Bahrain, PO Box 32038, Kingdom of Bahrain \\ ${ }^{3}$ College of Higher Studies, Arabian Gulf University, PO Box 26671, Kingdom of Bahrain
}

Received: 7 July 2021 / Received in final form: 14 September 2021 / Accepted: 14 September 2021

\begin{abstract}
The Gulf Cooperation Council Countries (GCCC) are largely engaged in renewable energy compared to other sources of energy for achieving sustainable development, i.e., maintaining balance between environmental, socio-economic and energy security and governance; this include mitigating climate change, reducing air pollution, improving energy access and enhancing energy security. According to IRENA report, by 2030, the GCCC could save 354 million barrels of oil equivalent (a $23 \%$ reduction), create more than 220,500 jobs, reduce the power sector's carbon dioxide emissions by $22 \%$, and cut water withdrawal in the power sector by $17 \%$ based on the renewables targets already in place. The GCCC have been undertaking renewable energy projects for more than 30 years but recently a trend for increasingly ambitious projects is being witnessed. These are being supported by renewable energy targets, innovative research and development, and investments across the entire industry value chain. The renewable energy targets in GCCC are as follows: Bahrain; $5 \%$ by 2025 (250 MW) and $10 \%$ by 2035, UAE; 30\% by 2030 (5000 MW), KSA; 30\% by 2040 (5400 MW), Oman 10 by 2020 (600 MW), Kuwait; $15 \%$ by 2030 (11,000 MW) and Qatar; $20 \%$ by 2030 (1800 MW). The paper highlight on the vast investment and applications carried in GCCC which can be considered as a transition phase in solar and wind energy use in these countries. It also suggests advantageous investments in sustainability in GCCC like investing in Electric Vehicle, Building Integrated PV or Building Integrated Wind Turbine, Rooftop PV for small -scale installation, and Solar and Wind Water Desalination.
\end{abstract}

\section{Introduction}

According to REN 21 report in 2019 [1], year 2018 witnessed relatively stable market for renewable energy technologies has been noticed. A total of $181 \mathrm{GW}$ of renewable power was added which makes the Global renewable power capacity to reach about 2378 GW in 2018. Around $100 \mathrm{GW}$ of solar photovoltaics (PV) was installed - accounting for $55 \%$ of renewable capacity additions followed by wind power (28\%) and hydropower (11\%). The Overall, renewable energy has grown to account for more than $33 \%$ of the world's total installed power generating capacity with more than 90 countries had installed at least $1 \mathrm{GW}$ of generating capacity, while at least 30 countries exceeded 10 GW of capacity. The Global investment in renewable power and fuels (not including hydropower projects larger than $50 \mathrm{MW}$ ) totaled USD 289 billion in

\footnotetext{
* e-mail: nalaser@uob.edu.bh
}

2018 which was the fifth in which it topped USD 280 billion. REN21, very recently [2], contains even better news as it had reported that the private sector signed power purchase agreements (PPAs) for a record growth of over $43 \%$ from 2018 to 2019 in new renewable power capacity.

It also reported [2] that climate change policies, directly or indirectly, stimulate interest in renewables increased in 2019, spreading to new regions and reaching new levels of ambition. Furthermore, the report stated that the support for renewable energy from public continued to advance alongside rising awareness of the multiple benefits of renewables, including reduction of carbon dioxide $\left(\mathrm{CO}_{2}\right)$ emissions. By the end of year 2019 there were 1480 jurisdictions - spanning 28 countries and covering 820 million citizens - had issued "climate emergency" declarations. The bad news is that the world is not on track to limit global warming to below $1.5^{\circ} \mathrm{C}$ as stipulated in the Paris Agreement [2].

The recent advancements, including well designed auctions, favorable financing conditions and declining 
technology costs, had let investments in GCCC to increase [2]. The prices of Solar PV in GCCC had become cheaper than the conventional electricity tariffs in GCCC; Large-scale solar PV started with a record-breaking $5.84 \mathrm{US}$ cents $/ \mathrm{kWh}$ bid in late 2014 in Dubai for the 200 MW Phase II of the MRM Solar Park (completed in 2017). In 2016, again in Dubai, records were broken with an astonishing $2.99 \mathrm{US}$ cents $/ \mathrm{kWh}$ bid for the 800 MW Phase III of the MRM Solar Park, of which 200 MW was completed in May 2018. These bids now look high compared with the 2.34 US cents $/ \mathrm{kWh}$ bid that won ACWA Power the 300 MW Sakaka project in Saudi Arabia. A similarly low price of $2.4 \mathrm{US}$ cents $/ \mathrm{kWh}$ was also seen for the $250 \mathrm{MW}$ of solar PV added to Phase IV of Dubai's MRM Solar Park in late 2018. CSP electricity joined in with a record 7.3 US cents/kWh for the 700 MW Phase IV of the MRM Solar Park in Dubai.

Major Renewable Energy Projects in GCCC are as follows [2]: Kuwait 70 MW of renewable capacity planned: solar photovoltaic (10 MW), concentrating solar power $(50 \mathrm{MW})$, wind (10 MW) ; Saudi Arabia 54 GW of renewable capacity by 2032: solar photovoltaic (16 GW), concentrating solar power $(25 \mathrm{GW})$, wind (9 GW), waste-to-energy (3 GW), geothermal (1 GW); Bahrain 250 MW including of waste-to energy; United Arab Emirates: Dubai; 5\% of final energy from renewables by 2030, Abu Dhabi; $7 \%$ of capacity from renewables by 2020 (100 MW of solar thermal capacity addition by early 2013 and $13 \mathrm{MW}$ of solar photovoltaic capacity addition by the end 2013 and announced/approved 28.8 MW of wind, $100 \mathrm{MW}$ of waste-to-energy and $100 \mathrm{MW}$ of solar photovoltaic; Oman: 100 to 200 MW of solar photovoltaic capacity addition announced; Qatar: 100 MW of solar photovoltaic capacity to be implemented by 2014 target to be announced.

Many research papers had focused on the emergent need for GCCC to be engaged in renewable energy utility and had advised these countries to strive away from fragile environmental quality the GCCC might face in future due to the intensive use of conventional energy sources to meet its future needs towards its property. For example, Al-Maamary et al. [3] conducted a general review on how GCCC suffer environmentally and suggested the practical steps to be taken by these countries (collectively and individually) to mitigate. Also, Al-Maamary et al. [4] reviewed how the climate change is affecting many sectors and systems in GCCC like water desalination, food security, and public health aiming to serves researchers; decision makers, politicians, and engineers. Kazem [5], although focusing on Oman, one of GCCC, the issues apply to other GCCC. His work was useful in discussing (and recommending) the appearance and weight of renewable energy in the higher education programs and the Oman commitment toward renewable energy. Moosa and Kazem [6], on the other hand, shed light on the status and prospects of renewable energy in GCCC targeting researchers, investors and decision makers. Tlili [7] described the current status of energy in the KSA (one of GCCC) and focused on renewable and energy-efficient technologies, major achievements, and current government policies and challenges in KSA - with suggestions applied to nearly all GCCC. Amran et al. [8] reported that some of Renewable Energy and Sustainable Energy (RE\&SE) technologies have not been used adequately at present in KSA (and probably other GCCC). Also, reported that there is a need to inspect the potential of offshore-wind, biomass, and thermal energy. The researchers provided comprehensive insight into the potential applications of RE\&SE technologies for developing a sound energy policy to attain energy security and reduce cost; thereby ensuring the efficiency of RE\&SE applications toward the long-term prosperity and energy reservation in the KSA.

The purpose of this paper is highlight on the vast investments and applications carried in the GCCC, which can be considered as a transition phase in solar and wind energy use in these countries.

\section{Solar and wind energy research in GCCC}

The research in renewable energy in GCCC, particularly solar and wind, is increasing and is concentering in further feasibility studies to use the large land in GCCC specially in Saudi Arabia. For example, a Monte Carlo Simulation (MCS) and Brownian Motion (BM) approaches were employed to predict the future behavior of solar and wind energy in Kingdom Saudi Arabia (KSA) [9], along with long-term temperature performance, based on 69 years of historical daily data. The results show that the north-western region in the KSA was the most highly recommended region for deployment of solar and wind energy applications due to an abundance of solar and wind energy resources with low temperature supported by a clearer sky during the year. This is followed by the southern region, which exhibited good solar and wind energy resources.

Furthermore, King Abdullah City for Atomic and Renewable Energy (KACARE) has launched a more comprehensive Renewable Resource Atlas in order to provide a solar and wind energy resource-monitoring system for live data recorded from 41 stations across the country for the use of researchers, developers, policy-makers, government institutions, and those working in risk-reduction [10] - the same was made in Bahrain [11], Oman [12]. The wind energy resource availability over GCCC's water (wind speed and wind power density), covering 2300 grid points and at different height 10,30 and $50 \mathrm{~m}$ has been reported in 2018 [13] - Figures 1 and 2.

In the KSA, the historical wind speed measurements (Fig. 3) and the evaluation of wind speed frequency distributions for different sites in Saudi Arabia had revealed that the wind resources reached relatively high levels along the coastlines (Tabuk) and lowest in the Middle (Riyadh). The wind speed was observed to be greater in the western mountains and the northern region, with good opportunity performance in the southern region of Saudi Arabia.

KACARE has developed a Renewable Resource Monitoring and Mapping (RRMM) program, which is in cooperation with the Battelle Memorial Institute and the United States-Based National Renewable Energy Laboratory to assist and evaluate the potential of solar and wind 

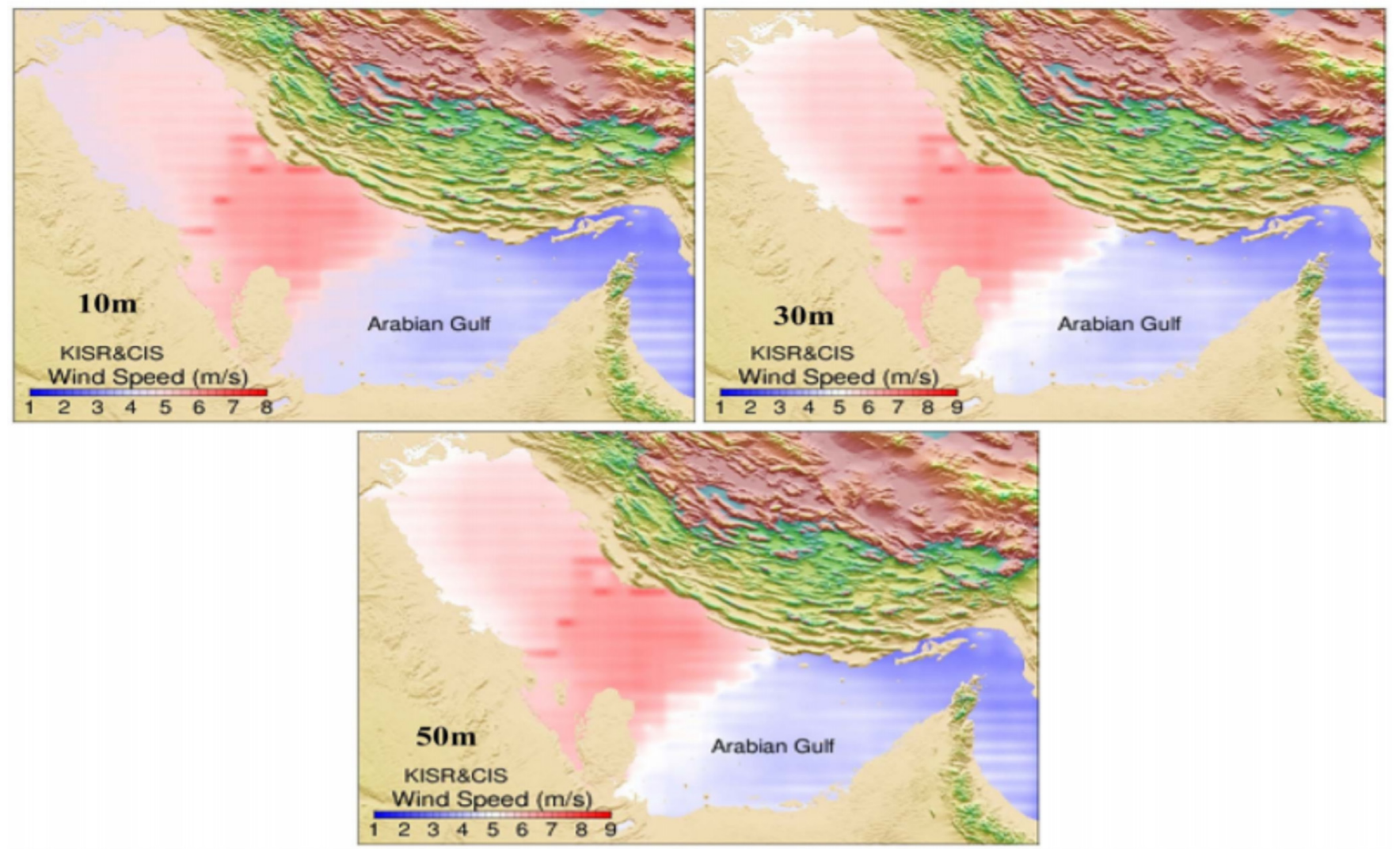

Fig. 1. Mean wind speed $\left(\mathrm{ms}^{-1}\right)$ at 10,30 and $50 \mathrm{~m}$ above sea level over. Arabian Gulf waters for periods of 1979-2015 [13].

energy [14]. The KACST and KACARE platforms monitor network resources aimed to measure and record solar and wind energy data at different locations in Saudi Arabia to improve renewable energy technologies [14,15].

Rehman et al. [10] recorded a speed of $5.74 \mathrm{~ms}^{-1}$, in KSA, as the highest mean wind speed in the region at a height of $40 \mathrm{~m}$. It was also reported that that higher wind speed values were recorded during the day and during the summer season, while lower wind speed values were recorded during the night and during the winter season [16].

Baseer et al. [17] performed an assessment to evaluate the wind speeds at different heights above ground level (10, 50, and $90 \mathrm{~m}$ ) for five sites at Jubail industrial city in the eastern province in Saudi Arabia. The highest mean wind speeds at the Jubail industrial site was $5.35 \mathrm{~ms}^{-1}$, and the possibility of wind speeds reaching above $3.5 \mathrm{~ms}^{-1}$ was $75 \%$ - this not very promising.

\section{Investing in wind energy for sustainability}

GCCC can use their sea shore which has a length of $3500 \mathrm{~km}$ where if wind turbines each has a power capacity of $8 \mathrm{MW}$ - rotor size 167-metres in diameter - providing a specific power rating of $365 \mathrm{~W} / \mathrm{m}^{2}$ at a hub height $150 \mathrm{~m}$, i.e., Siemens Gamesa SG 8.0-167 DD [18] that has cut - in speed $3 \mathrm{~m} / \mathrm{s}$, rated wind speed $12 \mathrm{~m} / \mathrm{s}$ and power density of $365.3 \mathrm{~W} / \mathrm{m}^{2}$-installed $1 \mathrm{~km}$ away from the coast at $2 \mathrm{~km}$ apart - then the total installed capacity will be about $10 \mathrm{GW}$ (annual wind electricity of $86 \mathrm{TWh}$ - assuming $70 \%$ yield from the maximum capacity $(14 \mathrm{GW})$. This a very large wind electricity yield, which is about $23 \%$ of installed wind turbine globally in 2019 (60.4 GW) according to Global Wind Report [19] - where the total capacity for wind energy globally is now over $651 \mathrm{GW}$, an increase of $10 \%$ compared to 2018 [18]. The GCCC generated electricity has grown from 51 TWh in the year 1990 to almost 536 TWh in the year 2015 [14]. Studies have shown that the GCCC will face a rapid increase in electricity demand by 2025 to reach 1093 TWh as in Figure 4 [20]. The electricity use per capita in all GCC countries is considered one of the highest rates of energy consumption per capita, in 2010 ranges from $5340 \mathrm{kWh}$ to $17,610 \mathrm{kWh}$, comparing to the world average which reaches $2728 \mathrm{kWh}$ and middle east average of $3378 \mathrm{kWh}$ [21].

Assuming that each wind turbine cost USD $40 \mathrm{~m}$ (including installation) then the required investment is US $\$ 70$ bn producing daily wind electricity about $86 \mathrm{TWh}$. This amount will fulfill $86 \%$ of the needed electricity demand in 2025. The cost per $\mathrm{kWh}$ will be about US $\$ 2.7$ if the wind turbines operates for 30 years!.

For this reason, GCCC plan to invest USD $\$ 100$ billion in renewable energy (RE) projects over the next 20 years and have set RE targets, i.e., KSA plans to generate $54 \mathrm{GW}$ of RE by 2040, Kuwait and Oman plan to increase the share of RE in the energy mix to $15 \%$ by 2030 and $30 \%$ by 2030 , 

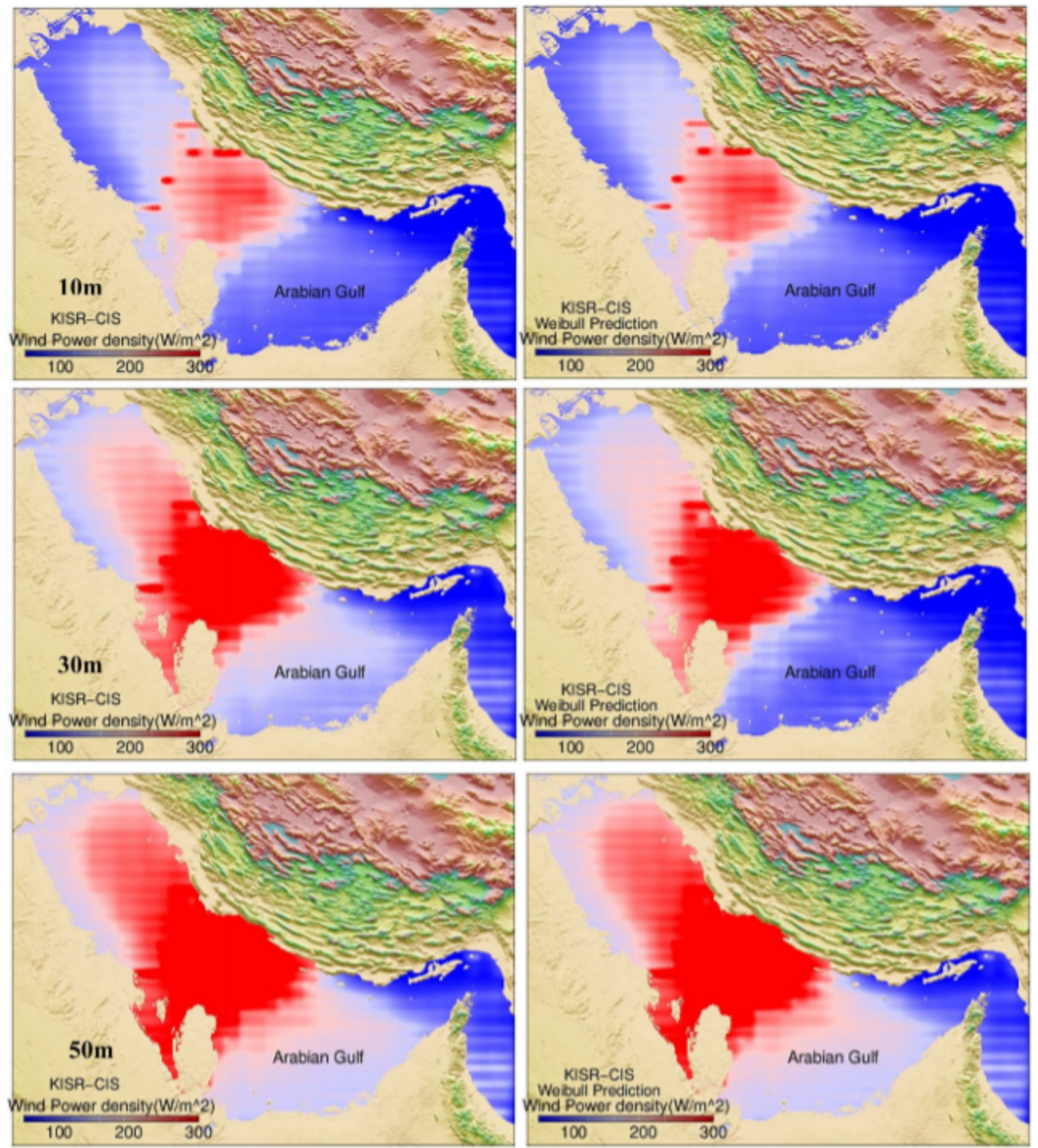

Fig. 2. Comparison of Weibull predicted and actual distribution of wind power density (Wm ${ }^{-2}$ ) at 10,30 and $50 \mathrm{~m}$ over Arabian Gulf Waters for periods of (1979-2015) [13]. 


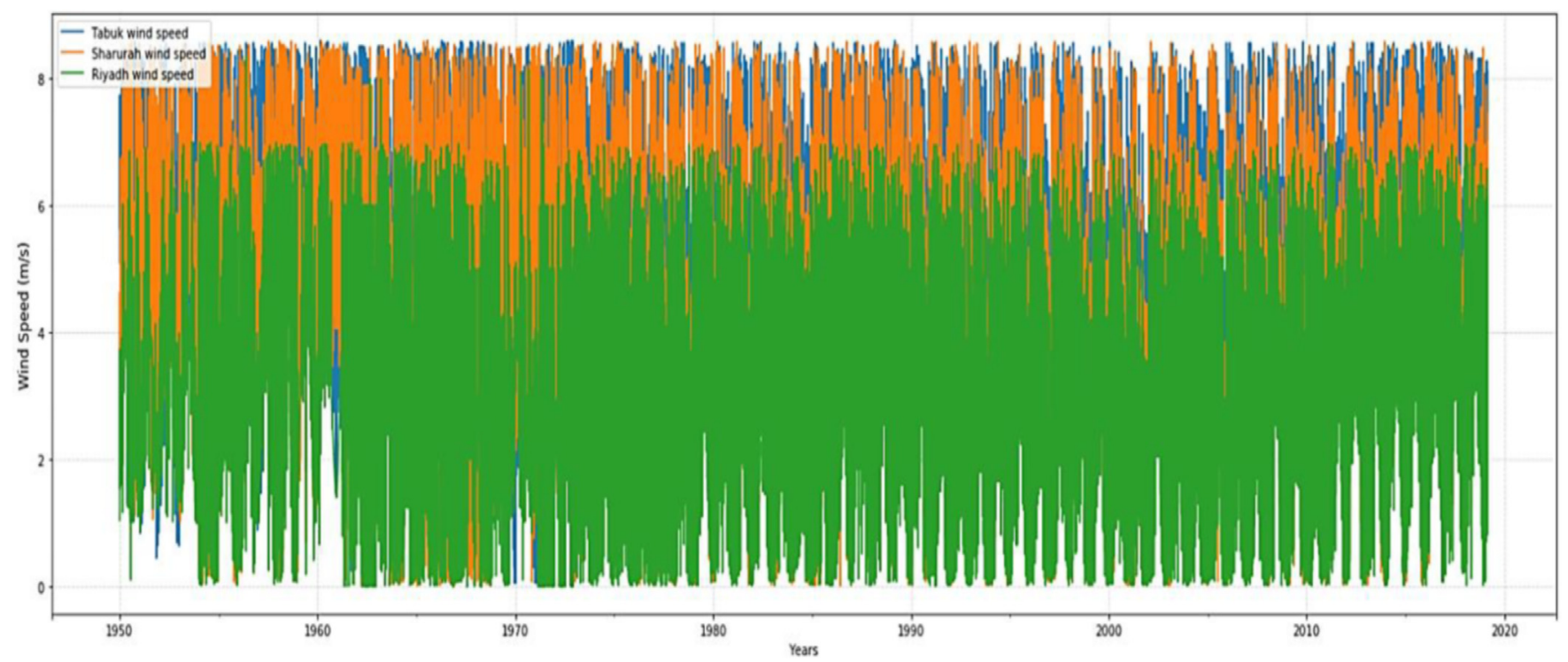

Fig. 3. The wind speed performance of the three regions [9]. The lowest wind speed is $0 \mathrm{~m} / \mathrm{s}$ and the highest is $8 \mathrm{~ms}^{-1}$.

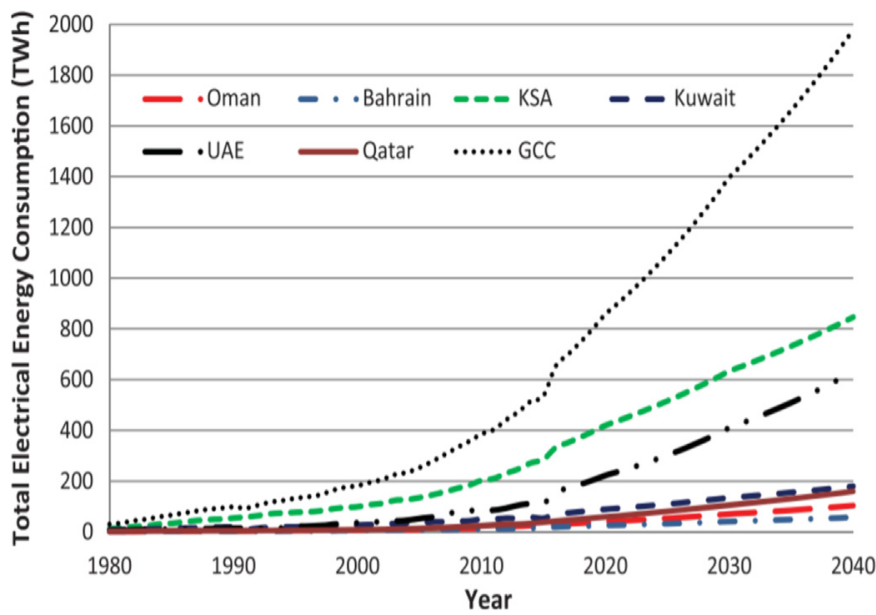

Fig. 4. Electrical energy consumption in the GCC, 1980-2040 [20].

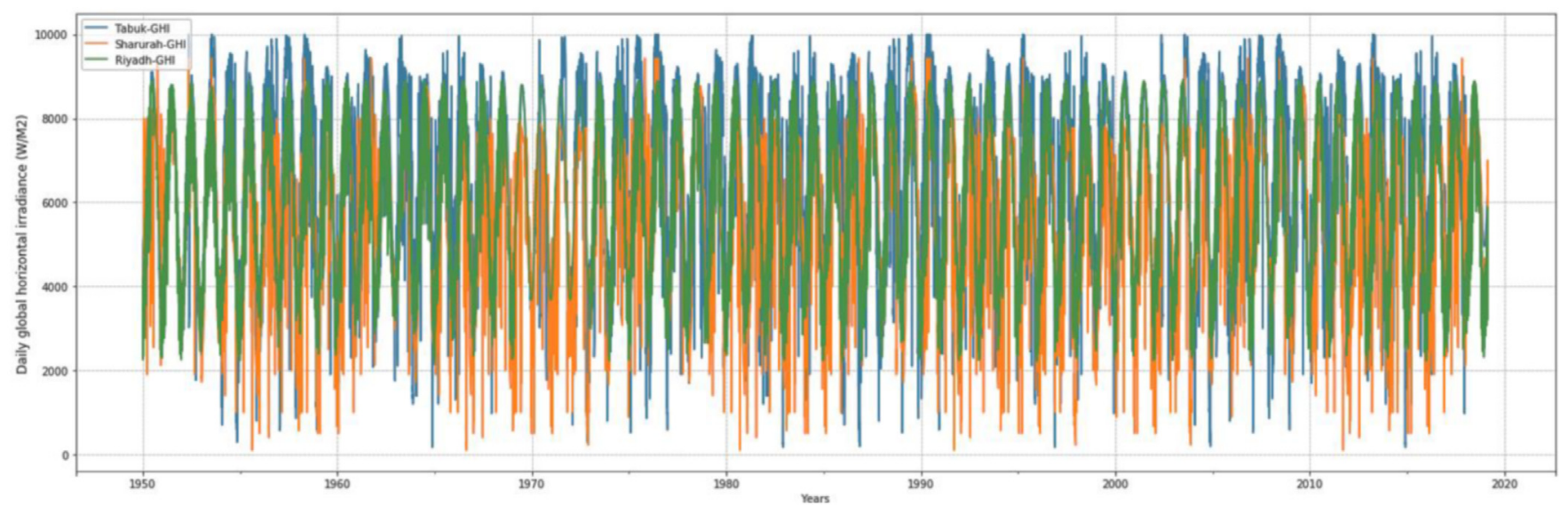

Fig. 5. The global horizontal irradiance (GHI) performance of the three regions from 1950 to 2020 [9]. The lowest line is $0 \mathrm{Wm}^{-2}$ and the highest line is $1000 \mathrm{Wm}^{-2}$. The highest GHI is in Riyadh and Tabuk and the lowest is in Sharurah. 


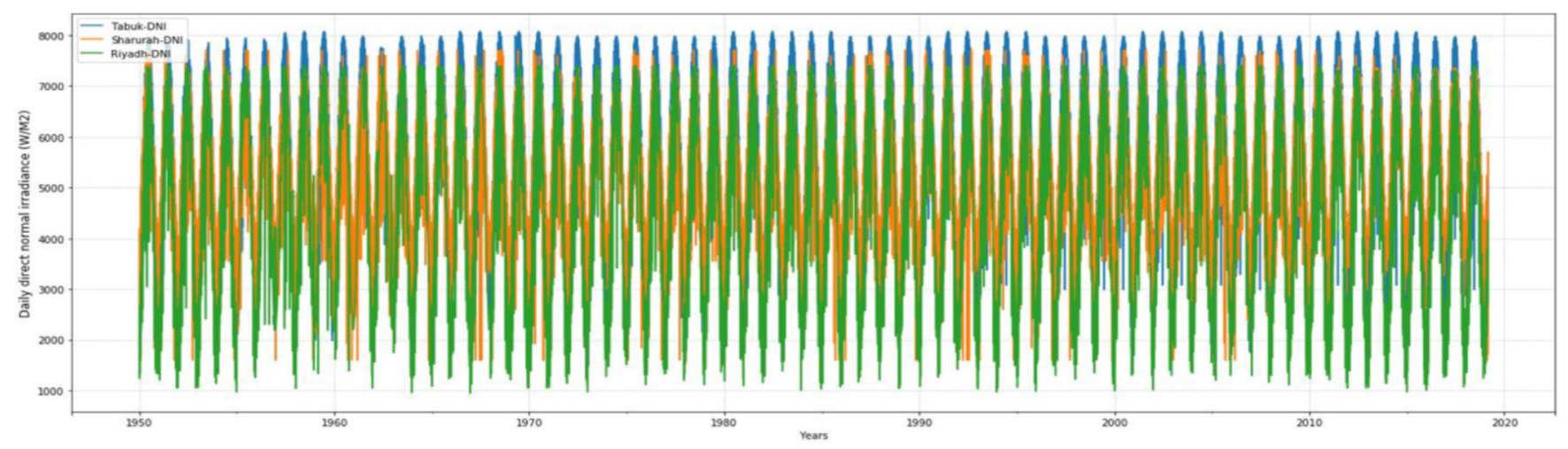

Fig. 6. The direct normal irradiance (DNI) performance of the three regions from 1950 to 2020 [9]. The lowest line is $100 \mathrm{Wm}^{-2}$ and the highest line is $800 \mathrm{Wm}^{-2}$. The highest DNI is in Tabuk and the lowest is in Riyadh.

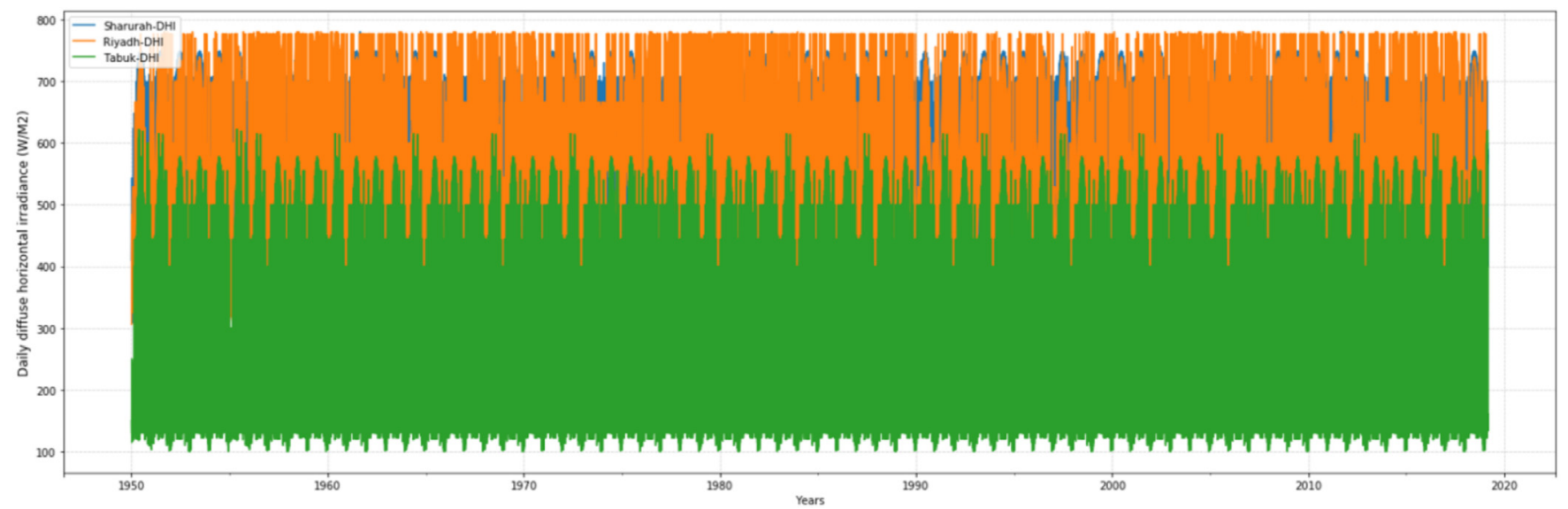

Fig. 7. The diffuse horizontal irradiance (DHI) performance of the three regions from 1950 to 2020 [9]. The lowest line is $100 \mathrm{Wm}^{-2}$ and the highest line is $800 \mathrm{Wm}^{-2}$. The highest DHI is in Riyadh and the lowest is in Tabuk.

respectively, UAE raised its clean energy target from $24 \%$ to $27 \%$ by 2021 and by 2050 to $44 \%$, Bahrain set $5 \%$ of capacity by RE by 2020, Qatar plans $20 \%$ RE out of 1800 MW capacity by 2030 [21].

Saudi Arabia has great potential opportunities to harness solar sources for solar energy applications [9] and can be a leading producer and exporter of solar energy generation as understood from Figures 5 to 7 [9].

Based on the results of Alharbi and Csala [9], the northwestern region of KSA exhibits higher daily total solar GHI and DNI (9.0 and $7.5 \mathrm{kWm}^{-2}$, respectively), supported by relatively low temperatures and clean skies. In addition, the north-western region has the best estimated daily average wind speeds (between 5.8 and $8.5 \mathrm{~ms}^{-1}$ ). The second promising region was the southern region, which exposed good daily total values of GHI and DNI (7.6 and $7.2 \mathrm{kWm}^{-2}$, respectively). The southern region showed good predictable daily average wind speed performance (between 4.8 and $8.57 \mathrm{~ms}^{-1}$ ), with adequate daily average wind speed distribution for the long-term and low temperature values. According to this research, Saudi Arabia has great opportunities to diversify its power system due to an abundance of potential solar and wind energy resources. Finally, after intensive evaluation and careful analysis of various aspects of solar and wind energy resources in the three studied regions, the north-western region is the most highly recommended region for solar and wind energy applications, followed by the southern region, which also exhibited strong solar and wind energy resources. The annual average solar radiation within the GCC countries is relatively equal to 1.1 barrel of oil equivalent per $\mathrm{m}^{2}$. The radiation is the highest in Kuwait, in June-July $\left(8200 \mathrm{kWhm}^{-2}\right)$ and the lowest in Oman $\left(6400 \mathrm{kWhm}^{-2}\right)[22]$. The radiation is low in January-December $\left(4200 \mathrm{kWhm}^{-2}\right.$ in the UAE and $3200 \mathrm{kWm}^{-2}$ in Bahrain) [23].

The GCC is among the most attractive regions in the world to develop large-scale solar and wind energy projects because of resource abundance and a favorable Policy environment, a fact that is backed up by record low price. The International Renewable Energy Agency (IRENA) has announced that renewable energy is the most competitive form of power generation in GCCC. Abundant resources, together with strong enabling 
Table 1. Mean yearly solar radiation in GCCC [13].

\begin{tabular}{|c|c|c|c|c|c|c|}
\hline Country & $\begin{array}{l}\text { Bahrain } \\
\text { E } 50^{\circ} 48^{\prime} \\
\text { N } 26^{\circ} 18^{\prime}\end{array}$ & $\begin{array}{l}\text { KSA } \\
\text { E } 50^{\circ} 30^{\prime} \\
\text { N } 26^{\circ} 36^{\prime}\end{array}$ & $\begin{array}{l}\text { UAE } \\
\text { E } 54^{\circ} 48^{\prime} \\
\text { N } 25^{\circ} 00^{\prime}\end{array}$ & $\begin{array}{l}\text { Kuwait } \\
\text { E } 48^{\circ} 18^{\prime} \\
\text { N } 29^{\circ} 12^{\prime}\end{array}$ & $\begin{array}{l}\text { Oman } \\
\text { E } 50^{\circ} 55^{\prime} \\
\text { N } 21^{\circ} 31^{\prime}\end{array}$ & $\begin{array}{l}\text { Qatar } \\
\text { E } 51^{\circ} 18^{\prime} \\
\text { N } 26^{\circ} 12^{\prime}\end{array}$ \\
\hline Annual Solar Radiation $\left(\mathrm{kWh} / \mathrm{m}^{2}\right)$ & $2,180[17]$ & $2,200[17]$ & $2,285[17]$ & $2,150[17]$ & $2,350[17]$ & $2,113[17]$ \\
\hline Average daily Solar Radiation $\left(\mathrm{kWh} / \mathrm{m}^{2}\right)$ & $5,180[19]$ & $5,670[19]$ & $6,300[17]$ & $5,990[19]$ & $5,410[19]$ & $5,260[19]$ \\
\hline Average daily Sunshine hours & $9.2[19]$ & $8.7[19]$ & $9.7[19]$ & $8.9[19]$ & $9.6[19]$ & $9.3[19]$ \\
\hline Average daily solar power density $\left(\mathrm{W} / \mathrm{m}^{2}\right)$ & 563.0 & 651.7 & 649.5 & 673.0 & 563.5 & 565.6 \\
\hline Average daily wind power densities $\left(\mathrm{W} / \mathrm{m}^{2}\right)$ & $299.9[7]$ & $277.6[7]$ & $120.8[7]$ & $162.5[7]$ & $120[26]$ & $274.7[7]$ \\
\hline $\begin{array}{l}\text { Ratio of Solar Power density } \\
\text { to Wind power density }\end{array}$ & 1.88 & 2.34 & 5.38 & 4.14 & 4.70 & 2.06 \\
\hline
\end{tabular}

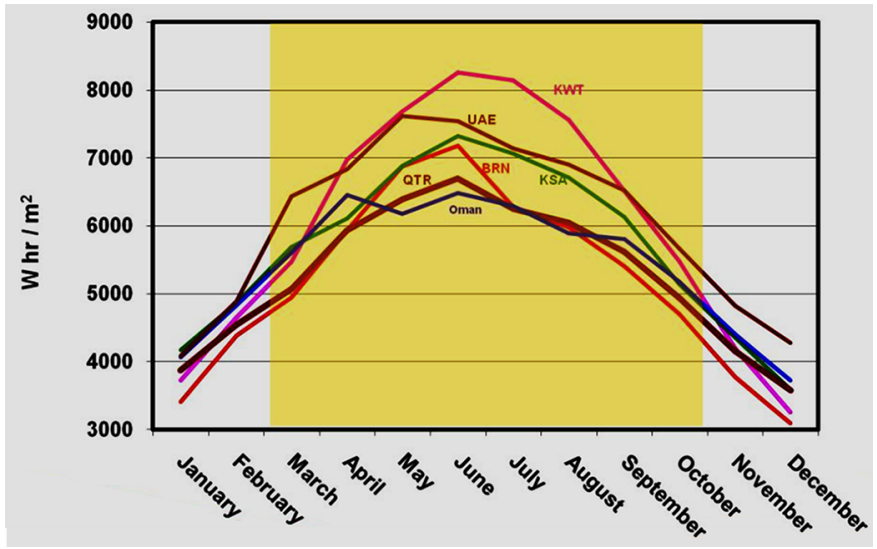

Fig. 8. The daily average solar radiation in GCCC [26].

frameworks have led to solar PV prices of below US\& 3 per $\mathrm{kWh}$ and dispatchable concentrated solar power (CSP) of US\& 7.3 per $\mathrm{kWh}$, which is less than some utilities in the region pay for natural gas [24].

Furthermore, achieving stated 2030 targets can bring significant economic benefits to the region including the creation of more than 220,000 new jobs whilst saving over 354 million barrels of oil equivalent (MBOE) in regional power sectors. The targets could reduce the power sector's $\mathrm{CO}_{2}$ emissions by 136 million tonnes (22\% reduction), while cutting water withdrawals in the power sector by 11.5 trillion litres $(17 \%)$ by late 2020 -which, unfortunately, it will not be possible due to COVID 19 pandemic that started in GCCC in late January 2020 and still predominating.

Table 1 [19] shows the solar and wind potential in all GCCC which was collected from different references. The ratio between daily average solar power density $\left(\mathrm{Wm}^{-2}\right)$ to the average daily wind power density lies from minimum value of 1.88 (Bahrain) to maximum value of 5.38 (UAE). It has to be noted that in the northern region of the GCC region, the wind power density at $10 \mathrm{~m}, 30 \mathrm{~m}$ and $50 \mathrm{~m}$ hub heights vary between 100 to $170 \mathrm{Wm}^{-2}, 180$ to $190 \mathrm{Wm}^{-2}$ and 200 to $220 \mathrm{Wm}^{-2}$, respectively [13] (Fig. 8).

\section{Investing in solar energy for sustainability}

Referring to Table 1 , if GCCC devoted only $5 \%$ of its land for installation of PV solar electricity - which is $130,000 \mathrm{~km}^{2}$ (total GCCC area is 2.6 million $\mathrm{km}^{2}$ ) then assuming that the average annual solar radiation is $2200 \mathrm{kWhm}^{-2}$ and the efficiency of PV panels are $15 \%$ then the annual yield solar electricity will be about 43,000 TWh. This mean that the expected energy demand in 2025-which is $1093 \mathrm{TWh}$ [20] - can be met easily and can be exported since the world total electricity final consumption reported by IEA in 2018 was $22,315 \mathrm{TWh}$ - which was higher than 2017 by $4.0 \%$ [27]. The investment in such a project will require $13 \mathrm{GW}-\mathrm{PV}$ which may cost US $\$ 130$ bn and the cost per $\mathrm{kW}$ will be US 4 per $\mathrm{kWh}$ - assuming 40 years life of PV.

The GCCC is striving hard to fulfill its commitments toward not only reducing $\mathrm{CO}_{2}$ or global warming but extends to meet all the 17th Sustainable Developments Goals by 2030 . The following sections will shed light on the transition of GCCC in clean energy and RE, particularly solar and wind.

\subsection{Progress in RE in Kingdom of Saudi Arabia}

KACARE oversees renewables programmes. The "Saudi Vision 2030" program includes plans to generate 9.5 GW of electricity from renewables by 2030 , of which $3.45 \mathrm{GW}$ are already planned for 2020. KSA has set up a National Renewable Energy Program (NREP), through which the government is implementing its Vision 2030 programme and aims to produce $10 \%$ of its power from renewables by 2023 [28].

In July 2017, the Renewable Energy Project Development Office (REPDO), of the Ministry of Energy, Industry and Mineral Resources announced the request for qualification (RFG) regarding a $400 \mathrm{MW}$ wind power tender in Dumat Al Jandal (Al Jouf region). The REPDO had already launched a first $700 \mathrm{MW}$ tender in April 2017 and shortlisted 25 companies, of which 4 consortia are still competing: Enel Green Power, EDF Energies Nouvelles, Engie and ACWA Power. The tender includes a $300 \mathrm{MW}$ solar PV tender in Sakaka (Saudi Arabia) and a 400 MW wind park [28]. 
In August 2017, KSA government unveiled a net metering framework to incentivize small-scale (less than $2 \mathrm{MW}$ ) solar power producers consuming their own generated electricity and selling the excess to the national grid [28].

KACARE, the King Abdullah City for Atomic \& Renewable Energy, was established in 2010 to develop nuclear and renewables programmes. In March 2018, Saudi Arabia approved a new nuclear policy, with plans to build up to 16 reactors for a total of $17.6 \mathrm{GW}$ for a total cost of around US\$80bn over the next two decades. These nuclear reactors could generate enough electricity to cover around $10 \%$ of the country needs by 2040 . The first two reactors had been announced in 2017 and would total 2.8 GW [28].

The Saudi Energy Efficiency Centre (SEEC) was created in 2010. It oversees developing policies, rules and regulations relative to energy efficiency and supports their implementation. In 2015, the Government committed to reduce primary consumption by $20 \%$ by 2030 as compared to a BAU scenario. A mandatory Building Code has been introduced in 2010 for government buildings. Labelling of appliances has been introduced for refrigerators and freezers, washing machines and air conditioners. Minimum energy efficiency standards were introduced for room air conditioners in 2001 [28].

The implementation of these standards is overlooked by the National Committee for Saudi Building Code. New fuel efficiency standards for light vehicles became effective in 2016, with the objective of reaching a $40 \mathrm{mpg}$ standard by 2025 (around $5.9 \mathrm{l} / 100 \mathrm{~km}$ ). New energy efficiency requirements for lighting products were also introduced in 2016 .

In 2016 , a target of $9.5 \mathrm{GW}$ by 2030 was introduced as part of the Vision 2030 reform plan with an intermediary objective of $3.5 \mathrm{GW}$ in 2020. This completes KACARE's ambitious renewable target of $54 \mathrm{GW}$ by 2040 set up in 2015 (initially announced in 2012 for 2032 ), made up of: $41 \mathrm{GW}$ of solar (PV: $16 \mathrm{GW}$; CSP: $25 \mathrm{GW}$ ), $9 \mathrm{GW}$ of wind, $3 \mathrm{GW}$ of biomass (waste) and $1 \mathrm{GW}$ of geothermal [28].

A $50 \mathrm{MW}$ CSP plant is under construction as part of the Duba ISCC 1 project (along with a $550 \mathrm{MW}$ gas-fired plant). Seven additional solar projects are planned, including the $180 \mathrm{MW}$ Taiba CSP plant, as well as $600 \mathrm{MW}$ worth of PV projects, including ACWA Power's 300 MW Sakaka project [28].

A $400 \mathrm{MW}$ onshore wind park is planned in Dumat Al Jandal. Four consortia are still competing in the corresponding REPDO tender, including EDF Energies Nouvelles, Engie, ACWA Power and Enel Green Power.

The Saudi government plans to select a project developer for its first nuclear power plant in 2019. KEPCO, Rosatom, along with other bidders from China, France and the United States were shortlisted in July 2018.

According to the Nationally Determined Contribution (NDC) submitted following the COP 21, Saudi Arabia intends to reduce its GHG emissions until achieving a reduction of $130 \mathrm{MtCO}_{2}$ eq by 2030 as compared to a BAU scenario. $\mathrm{CO}_{2}$ emissions from energy combustion per capita are among the highest in the world and reached $17.8 \mathrm{tCO}_{2} /$ capita in 2017, similar to other Gulf countries (6th largest per capita emitter in the world in 2017). $\mathrm{CO}_{2}$-energy emissions have increased strongly since $1990(+5 \%$ year $)$ and reached $589 \mathrm{MtCO}_{2}$ in 2017 [28].

\subsection{Progress in RE in Bahrain}

The electricity and water affairs launched the National Renewable Energy Action Plan (NREAP), which revises the previous renewable target to $5 \%$ of the energy mix by 2025 and $10 \%$ by 2035 (previous target set at $5 \%$ of the electricity capacity in 2020 in Vision 2030 Economic Plan) [29].

In 2018, EWA launched a net metering policy for residential, commercial and industrial customers to encourage renewable power production for self-consumption and to facilitate a smooth connection with the national grid. Under NREAP, EWA will launch several competitive tenders for renewable power projects installed on government buildings and require real estate developers to integrate renewable energy technologies into building design.

Bahrain's electricity and water master plan provides a roadmap to guide the country's infrastructure development until 2030. The plan projects that peak system demand will almost double from 3.4 GW in summer 2016 to 6.5 GW by 2030.

Under NREAP, Bahrain targets $255 \mathrm{MW}$ of solar PV capacity by 2025 to meet $5 \%$ of the country's power demand, and 700 MW by 2035. In 2018, the EWA issued a request for bids from IPPs for a $100 \mathrm{MW}$ solar PV project at a remediated landfill site.

In February 2019, this tender has been awarded to a consortium including ACWA Power (Saudi Arabia), Mitsui and the Bahraini industrial conglomerate AlMoayyed, with a US\$3.9c/kWh bid [29].

The government of Bahrain has not set a $\mathrm{CO}_{2}$ emissions reduction target, but it has launched strategies, plans and actions to contribute to lower greenhouse gas emissions. $\mathrm{CO}_{2}$ emissions from energy use are increasing rapidly (4\%/year since 2004) and reached $32 \mathrm{MtCO}_{2}$ in 2017 [29].

\subsection{Progress in RE in UAE}

The UAE targets for RE is to cover $44 \%$ of its energy consumption with renewables by 2050 (Energy Strategy 2050). Abu Dhabi has set a goal of generating $7 \%$ of its electricity from renewables by 2020, while the share of renewables in Dubai's power mix is expected to reach $15 \%$ in 2030 [30].

UAE Government has set a GHG emission reduction target of $15 \%$ by 2021 to respect one of the goals of the UAE Vision 2021, and a target of $70 \%$ by 2050 in the Energy Strategy 2050. UAE's NDC does not specify quantitative reduction targets.

The Government has initiated a National Agenda, UAE Vision 2021, including several measures and targets in the field of energy. The Agenda targets a share of $27 \%$ total energy consumption coming from non-fossil energy sources (renewables and nuclear) by 2021. In 2017, the UAE Energy Plan 2050 was approved, with the aim of increasing the use of non-fossil energy sources to $50 \%$ of the total energy consumption, of which $44 \%$ renewables and $6 \%$ nuclear, and increasing energy independence overall, for a planned investment of US\$163.3bn [30]. 
Dubai has posted even more ambitious targets: the Emirate aims to cover $25 \%$ of its energy consumption with renewable energy sources (exclusively solar) by 2030 and to reach $75 \%$ of clean energy sources by 2050 . It has launched the Dubai Clean Energy Strategy 2050, which aims at attracting $\mathrm{R} \& \mathrm{D}$ centers and make the emirate a global center for renewables. A US\$27bn Dubai Green Fund will be established to provide soft loans for investments in the clean energy sector.

In 2014, the Ministry of Energy established a new department for energy conservation and energy efficiency. The UAE Energy Strategy 2050 aims at improving energy efficiency by $40 \%$ by 2050 . $\mathrm{CO}_{2}$ emissions from energy use increased rapidly until 2016 (5.2\%/year since 2000), and have been decreasing slightly since then $(-1 \% /$ year $)$ [30].

The UAE plans to invest massively in solar energy to meet their objectives regarding the development of renewables. A total of $4.9 \mathrm{GW}$ of solar projects are currently planned or authorized.

The third phase of 800 MW of DEWA's Mohammed Bin Rashid Al Maktoum Solar Park is expected to be completed in 2020. With the objective of raising the solar park's total capacity to 5000 MW by 2030, the fourth phase will consist of a 950 MW CSP project. In 2018, DEWA signed an EPC contract with Saudi Arabia's ACWA Power and China's Shanghai Electric. The US $\$ 3.9$ bn project will include a $600 \mathrm{MW}$ parabolic basin complex and a 100 MW solar tower and should be commissioned in late 2020 at the earliest for an expected LCOE of US\$7.3 per kWh [30].

FEWA plans to invest US\$135m in the construction of $200 \mathrm{MW}$ of solar power projects in the Northern Emirates. The projects would-be built-in partnership with the private sector and is expected to be commissioned in 2025 .

In 2016, DEWA announced plans to build a $250 \mathrm{MW}$ pumped-storage project in Hatta. The project will be in the mountains next to the Al Hattawi dam and will include solar power capacities to pump water from the existing lower reservoir to the upper reservoir that will be built. DEWA completed engineering studies in 2018 and the project is now expected to be completed by 2024 .

Four biomass power plant projects are planned, both using waste as fuel: Ruwais (230 MW), Warsan (171 MW), the TAQA project (100 MW), and Sharjah-1 (30 MW, under construction). The plant in Sharjah will use up to 300000 tons of waste per year and convert it into electricity [30].

\subsection{Progress in RE in Kuwait}

Kuwait set an ambitious goal to generate $15 \%$ of its electricity from renewables by 2030 , as part of the goals set in its New Vision 2035 [25]. In April 2018, Kuwait ratified the Paris agreement, thus validating its Nationally Determined Contribution (NDC). The NDC implies a commitment to set up a transition to a low-carbon economy, without a quantitative target.

Minimum energy efficiency requirements for all new and retrofitted buildings have been enforced by MEW since 1983, through a regularly updated Energy Conservation Code of Practice. Since 2010, the Energy Efficiency
Technologies programme managed by the Kuwait Institute of Scientific Research is developing energy efficiency projects, mainly in buildings (reinforcing compliance with the energy code, energy performance of buildings and establishing demand side management and photovoltaic systems in schools) [31].

The Al-Shagaya Renewable Energy Park is expected to comprise around $250 \mathrm{MW}$ of CSP (of which $50 \mathrm{MW}$ operational), and $2.7 \mathrm{GW}$ of PV; it will be an essential component of Kuwait's objective to reach $15 \%$ of renewable electricity in 2030. In 2018, KNPC initiated a tender for five blocks of $300 \mathrm{MW}$ each. The successful bidder will provide operation and maintenance for 25 years, and the construction of this phase is expected to be completed in 2022 [31].

A 280 MW hybrid power plant (220 MW CCGT and $60 \mathrm{MW}$ solar CSP) located in Al-Abdaliya should be built at a cost of US\$3.3bn and is expected to be commissioned in 2020 [31].

A wind project of $100 \mathrm{MW}$ is announced as part of Phase 3 of the Shagaya Renewable Energy Park. This phase is scheduled for 2025/2026 [31].

Energy-related $\mathrm{CO}_{2}$ emissions doubled between 2000 and 2015 and have remained stable since then (92 Mt in 2018).

\subsection{Progress in RE in Oman}

In January 2020, OPWP at Oman has revised its renewable energy development plan, which now aims to reach $3 \mathrm{GW}$ of renewables by 2025 , to cover $16 \%$ of the power mix. This is an increase from previous plans, which targeted $10 \%$ of renewables by 2025. By 2030, Oman aims to reach $30 \%$ of renewable power capacity [32].

In 2018, Glasspoint Solar and Occidental Petroleum have signed a MoU for the development of a 2 GW solar thermal power plant at the Mukhaizna oil. The proposed CSP project would produce up to 100000 barrels of solar steam per day, which would be then be purchased by Occidental of Oman under the framework of a long-term offtake agreement and be used to facilitate production of heavy oil at the field.

In March 2019, a consortium comprising ACWA Power and Kuwait's Gulf Investment Corporation and Alternative Energy Projects Company has won a US\$400m bid to build the 500 MW Ibri-2 solar project for OPWP [32].

The project will be developed under the IPP model and will be located in Ibri, around $300 \mathrm{~km}$ west of Muscat. It will start commercial operations in early 2021.

RAECO and Masdar (50/50 joint venture) launched the first wind project in Dhofar, with a capacity of $50 \mathrm{MW}$. The investment is estimated at US\$125m. Construction began in 2018 and commissioning is expected for late 2019. During the same time, the second phase of this wind farm (150 MW) has been authorized and should be commissioned in 2023 [32].

In 2015, Oman submitted its Intended Nationally Determined Contribution (INDC) to UNFCCC, which has not been ratified yet. The target for 2030 is to reduce its GHG emissions by $2 \%$ compared to a BAU level. $\mathrm{CO}_{2}$ emissions from energy uses have been growing very rapidly (about 8.5\%/year between 2005 and 2015) but have 
slightly decreased since then. $\mathrm{CO}_{2}$ emissions per capita are among the 15 highest in the world with around $14 \mathrm{CO}_{2} /$ cap (2017) [32].

\subsection{Progress in RE in Qatar}

Qatar strives to meet $20 \%$ of its energy demand from renewable sources by 2030. It aims to reach a solar power capacity of $1800 \mathrm{MW}$ by 2020 , for a cost estimated between US $\$ 10 \mathrm{bn}$ and US $\$ 20 \mathrm{bn}$.

Although the first solar-panel factory was inaugurated in 2014 (300 MW/year), plans to generate renewable electricity have been delayed for years. The construction, in the long term, of a large $3.5 \mathrm{GW}$ solar complex is currently frozen. In 2016, Karahmaa set up a partnership with QP (Karahmaa 60\%, QP 40\%) for $1000 \mathrm{MW}$ of solar capacity (US $\$ 500 \mathrm{~m})$. However, their first $200 \mathrm{MW}$ solar project, which broke ground in 2017, is not expected to start operation before 2020 [33].

In May 2018, Karahmaa launched a solar tender for a 500 MW solar PV plant near Al Kharsaa. The projects will be developed on a BOOT basis, with Kahramaa providing a 25-year PPA. Commercial operation is expected in December 2020 [33].

Although Qatar submitted an Intended Nationally Determined Contribution (INDC) in preparation of the COP21 and ratified the Paris agreement in April 2016, no firm commitments were made to reduce its GHG emissions. $\mathrm{CO}_{2}$ emissions from fossil fuel combustion have increased more than threefold since 2000 , from $24 \mathrm{MtCO}_{2}$ to $87 \mathrm{MtCO}_{2}$ in 2017 (+9\%/year). Qatar's carbon intensive economy, combined with a low population density, leads to the highest level of per capita emissions in the world $34 \mathrm{t} \mathrm{CO}_{2} /$ capita).

\section{Conclusion}

There were vast investments and applications carried in the GCCC, which can be considered as a transition phase in solar and wind energy use in these countries.

Renewable energy has lots of striking benefits to GCCC. These countries use niche technologies with little application beyond small scale pilot projects where the project pipeline has grown to almost $7 \mathrm{GW}$ of new power generation capacity. Record-breaking bids in renewable energy auctions in Saudi Arabia and the UAE in 2016-2018 have, in fact, made solar power cost-competitive with conventional energy technologies. This is expected to further boost renewables in the region - and the world - in the coming years.

GCCC has significant solar and wind potential and has the interest in developing these resources as an economic alternative to domestic gas supply. Wind resources is found to complement solar power, particularly by tapping their offshore wind potential. Wind power should not remain a distant second to solar in the GCCC since their lots of potential in off-shore which extent to $3500 \mathrm{~km}$.

The key developments outlined in this paper could help in accelerating the deployment in the GCCC in achieving the SDGs by 2030 which is supported by the set policies and targets, adopted at both national and sub-national levels, drive incentives, remove market barriers and helping markets to harvest the multiple benefits associated with renewable energy. There are other an additional potential for investing in sustainability projects in GCCC. These are:

Electric Vehicle: The number of vehicles in GCCC is around 20 million burning about 115,000 million gallons of fuel which is resulting in $\mathrm{CO}_{2}$ emission of $6.3 \times 10^{11} \mathrm{~kg}(630$ million tonne). Using Electric Vehicle (like Tesla) that can be charged using solar and wind electricity will make breakthrough in reduction of emission and protecting GCCC environment and worldwide.

United Arab Emirates (UAE) and Saudi Arabia are becoming early adopters of electric vehicles (EVs) in the GCCC - even though it is still cheaper, in both countries, to drive an internal-combustion engine vehicle than EVs, their efforts are encouraging [33]. GCCC are promoting themselves as a country committed to a low-carbon and sustainable economy and have ambitious goal to boost its EV market in the next 20 years. The UAE government aims to boost its own EV use by $20 \%$ in 2020 as well as roll out 42,000 EVs across the country by 2030 [34].

Building integrated PV or building integrated wind turbine: If future houses and building are Building Integrated PV (BIPV) or Building Integrated Wind Turbine (BIWT), then charging such cars can be at zero cost beside this the houses becomes smart and sustainable buildings. There are many successful experiences in GCCC in both BIWT and BIPV. The Bahrain World Trade Centre is the World First BIWT $[35,36]$ which produces approximately 1.1 to $1.3 \mathrm{GWh}$ per year. Thin film solar cells would produce a better energy yield $(\mathrm{kWh} / \mathrm{kWp})$ in warm climates (such as that of the GCCC) while thin film and crystalline solar cells would perform equally well in colder climates further from the equator [37]. There are many successful BIPV projects in GCCC [38].

Rooftop PV for small-scale installation: Rooftop and small-scale installations Rooftop solar programmes remain a niche market in GCCC, with the UAE taking the lead through small scale schemes to encourage rooftop applications. As of October 2018, 49.9 MW of solar PV rooftop projects had been installed under net metering in Dubai, and connection requests for another $323 \mathrm{MW}$ of projects had been received; this is up from just 17.7 MW in 450 buildings in October 2017 [39]. In late 2017, Abu Dhabi started its own net metering policy, which is structured like the policy in Dubai [40]. Other GCCC are striving to promote Rooftop and cooperating with banks to offer loans at low interest and fast procedures. Bahrain, through Sustainable Energy Authority (SEA) can be set as a good example.

Solar and wind water desalination: Masdar in $\mathrm{Abu}$ Dhabi, in 2013, launched RE desalination pilot program to research and develop energy-efficient, cost-competitive desalination technologies that are suitable to be powered by renewable energy [41]. The long-term goal is to implement RE-powered desalination plants in the United Arab Emirates, as well as other GCCC and MENA Countries and to have a commercial scale facility operating by 2020. Four commercial partners - Abengoa, Suez, Sidem/Veolia and Trevi Systems - were selected to support the development of the program. Each of them 
was to develop and operate a next-generation pilot seawater desalination plant. The four plants are to test a range of innovative approaches in boosting operational efficiency. Investing in RE solar water desalination is very vital as all GCCC desalinate the water (90\% of water resources) - mainly using thermal power or RO technology using conventional energy.

All these conducted grand projects in renewable energy (solar and wind) as well the suggested investment in sustainability will strive the GCCC to fly beyond the huddles of oil prices fluctuation in maintaining its prosperity [42].

\section{References}

1. REN 21 (2019) Renewables 2019 Global Status Report, https://www.ren21.net/gsr-2019/

2. REN 21 (2020) Renewables 2020 Global Status Report, https://www.ren21.net/renewables-report-launch/

3. H.M. Al-Maamary, H.A. Kazem, M.T. Chaichan, Changing the energy profile of the GCC States: A review, Int. J. Appl. Eng. Res. 11, 1980 (2016)

4. H.M. Al-Maamary, H.A. Kazem, M.T. Chaichan, The impact of oil price fluctuations on common renewable energies in GCC countries, Renew. Sustain. Energy Rev. 76, 555 (2017)

5. H.A. Kazem, Renewable energy in Oman: status and future prospects, Renew. Sustain. Energy Rev. 15, 3465 (2011)

6. I.S. Moosa, H.A. Kazem, Review of basic renewable energy in GCC countries: current status and future vision, Int. J. Comput. Appl. Sci. 6, 397 (2019)

7. I. Tlili, Renewable energy in Saudi Arabia: current status and future potentials, Environ. Dev. Sustain. 17, 859 (2015)

8. Y.A. Amran, Y.M. Amran, R. Alyousef, H. Alabduljabbar, Renewable and sustainable energy production in saudi arabia according to saudi vision 2030; current status and future prospects, J. Clean. Product. 247, 119602 (2020)

9. F. Alharbi, D. Csala, Saudi Arabia's Solar and Wind Energy Penetration: Future Performance and Requirements, Energies 13, 588 (2020)

10. S. AlYahya, M.A. Irfan, Analysis from the new solar radiation Atlas for Saudi Arabia. Sol. Energy Solar Energy, Solar Energy 130, 116 (2016)

11. Sustainable Energy Unit in Wind Energy Resources: Kingdom of Bahrain, EMD International A/5, Kingdom of Bahrain, 2015. file://C:/Users/UOB/Desktop/Wind\% 20Atlas\%20Report\%20Bahrain.pdf

12. Wind Resource Atlas Of Sultanate Of Oman, Final Report in Rimal Global Technical Services L.L.C. (Rimal), 2015, Oman. https://www.diam.om/PublicationsDoc/05-WindResource-Atlas

13. K. Al-Salem, S. Neelamani, W. Al-Nassar, Wind Energy Map of Arabian Gulf, Nat. Resourc. 9, 212 (2018)

14. E. Zell, S. Gasim, S. Wilcox, S. Katamoura, T. Stoffel, H. Shibli, J. Engel-Cox, M. Al Subie, Assessment of solar radiation resources in Saudi Arabia, Solar Energy 119, 422 (2015)

15. S.H. Alawaji, N.N. Eugenio, U.A. Elani, Wind energy resource assessment in Saudi Arabia: Part II: Data collection and analysis, Renew Energy 9, 818 (1996)
16. S. Rehman, A. Ahmad, L.M. Al-Hadhrami, Detailed analysis of a 550-MW installed capacity wind farm in Saudi Arabia, Int. J. Green Energy 7, 410 (2010)

17. M.A. Baseer, J.P. Meyer, M.M. Alam, S. Rehman, Wind speed and power characteristics for Jubail industrial city, Saudi Arabia Renew, Renew. Sustain. Energy Rev. 52, 1193 (2015)

18. Wind Power Monthly (2018) https://www.windpower monthly.com/10-biggest-turbines

19. Global Wind Energy Council (2018) https://gwec.net/gwecover-60gw-of-wind-energy-capacity-installed-in-2019-thesecond-biggest-year-in-history/\#:囚:text=GWEC\%20has\% 20published $\% 20$ the $\% 2015$,best $\% 20$ year $\% 20$ for $\% 20$ wind $\%$ 20historically

20. A. Al-Badi, I. AlMubarak, Growing energy demand in the GCC countries, Arab J. Basic Appl. Sci. 26, 488 (2019)

21. International Renewable Energy Agency (IRENA) (2012). Retrieved from http://www.irena.org/DocumentDown loads/Publications/_MiddleEastComplete.pdf

22. A.A. Mas'ud, A.V. Wirba, S.J. Alshammari, F. MuhammadSukki, M.M. Abdullahi, R. Albarracín, M. Ziaul Hoq, Solar Energy Potentials and Benefits in the Gulf Cooperation Council Countries: A Review of Substantial Issues, Energies 11, 372 (2018)

23. W.E. Alnaser, N.W. Alnaser, The status of renewable energy in the GCC countries. Renew. Sustain. Energy Rev. 15, 3074 (2011)

24. IRENA (2019) https://www.irena.org/newsroom/pressre leases/2019/Jan/Renewable-Energy-the-Most-CompetitiveSource-of-New-Power-Generation-in-GCC

25. K. Burashid, An overview of solar \& wind energy in the Kingdom of Bahrain and the GCC States - PowerPoint PPT Presentation, Amman 27-28 March 2012 (2012), https:// www.slideserve.com/oliver-myers/an-overview-of-solarwind-energy-in-the-kingdom-of-bahrain-and-the-gcc-states

26. H.A. Kazem, M.T. Chaichan, A.H.A. Al-Waeli, J.H. Yousif, K.H.A. Al-Waeli, Wind Resource Assessment for nine locations in Oman using weather data, Int. J. Comput. Appl. Sci. 3, 2399 (2017)

27. International Energy Agency (IEA) (2021) https://www.iea. org/reports/electricity-information-overview

28. Enerdata (2018) Country Energy Report: Saudi Arabia, August 2018

29. Enerdata (2019) Country Energy Report: Kingdom of Bahrain, March 2019

30. Enerdata (2019) Country Energy Report: United Arab Emirates, September 2019

31. Enerdata (2019) Country Energy Report: Kuwait, December 2019

32. Enerdata (2019) Country Energy Report: Oman, December 2019

33. Enerdata (2019) Country Energy Report: Oman and Qatar, December 2019

34. S. Berdikeeva, Inside Arabia: Voice of the Arab People (2020) https://insidearabia.com/electric-vehicle-markets-emergein-oil-rich-uae-and-saudi-arabia/

35. IRENA in Renewable Energy Market Analysis: GCC 2019, AbuDhabi, ISBN 978-92-9260- 096-9. https://www.irena. org/-/media/Files/IRENA/Agency/Publication/2019/ Jan/IRENA_Market_Analysis_GCC_2019.pdf 
36. Wikipedia, https://en.wikipedia.org/wiki/Bahrain_World_ Trade Center

37. W.E. Ālnaser, H. Timme, H. Albuflasa, N.W. Alnaser, Wind Characteristics and Wind Power Analysis in Bahrain for Building Integrated Wind Turbine Applications and CO2Emission Reduction, J. Assoc. Arab Univ. Basic Appl. Sci. 4, 298 (2007)

38. A. Asghar, M. Emziane, in Sustainability in Energy and Buildings, Smart Innovation, Systems and Technologies, 2012, edited by N. M'Sirdi, A. Namaane, R.J. Howlett, L.C. Jain, Springer, Berlin, Heidelberg, 2012, Vol. 12

39. GTV Global, 2020 https://gtv-global.com/bipv-2/
40. A. Assi, K.A. Kathairi, M. Jama, Building integrated photovoltaic (BIPV) in the United Arab Emirates - Tool and case study, in Proceeding of the 5th IEEE GCC Conference \& Exhibition, Kuwait City, 2009, p. 1

41. M. El Ramahi, in The Water, Energy, and Food Security Nexus in the Arab Region Case Study: Masdar Renewable Energy Water Desalination Program, P.209, December 2017. DOI: $10.1007 / 978-3-319-48408-2 \_11$

42. H.M. Al-Maamary, H.A. Kazem, M.T. Chaichan, The impact of oil price fluctuations on common renewable energies in GCC countries, Renew. Sustain. Energy Rev. 75, $989(2017)$

Cite this article as: Naser Waheeb Alnaser, Hanan Mubarak Albuflasa, Waheeb Essa Alnaser, The Transition in Solar and Wind Energy Use in Gulf Cooperation Council Countries (GCCC), Renew. Energy Environ. Sustain. 7, 4 (2022) 